CLINICAL STUDY

\title{
Exploring the use of recombinant human TSH in the diagnosis of central hypothyroidism
}

\author{
Helena Filipsson, Ernst Nyström and Gudmundur Johannsson \\ Department of Endocrinology, Sahlgrenska Academy at Göteborg University, Sahlgrenska University Hospital, Gröna Stråket 8 , \\ SE-41345 Göteborg, Sweden \\ (Correspondence should be addressed to H Filipsson; Email: helena.filipsson@telia.com)
}

\begin{abstract}
Context: The diagnosis of central hypothyroidism $(\mathrm{CH})$ is often difficult to establish as serum TSH levels may be low, normal, or slightly increased.

Objective: To explore the use of recombinant human TSH (rhTSH) in the diagnosis of $\mathrm{CH}$.

Design: Randomized single-blind clinical trial.

Setting: Outpatient clinic of a tertiary care referral center.

Intervention: A single intramuscular injection of 0.1 and $0.9 \mathrm{mg}$ rhTSH in random order with 1-week interval.

Participants: Eighteen adult patients with pituitary insufficiency and six healthy age-, sex-, and body mass index-matched controls. Six patients had untreated $\mathrm{CH}(\mathrm{newCH})$, six had treated $\mathrm{CH}(\mathrm{CH})$, and six patients were TSH sufficient (nonCH). Five weeks before TSH stimulation, levothyroxine was replaced with tri-iodothyronine $\left(\mathrm{T}_{3}\right)$ for 4 weeks. One week before stimulation, treatment was withdrawn.

Main outcome measures: Thyroid hormones and thyroglobulin (Tg) before and 2, 31/2, 7, 24, 48, and $72 \mathrm{~h}$ after each injection.

Results: In the newCH group, basal free thyroxine $\left(\mathrm{FT}_{4}\right)$ levels were lower than in controls $(P<0.05)$. After $0.9 \mathrm{mg}$ rhTSH, the increases in $\mathrm{FT}_{4}$ and reverse $\mathrm{T}_{3}\left(\mathrm{rT}_{3}\right)$ were less marked in the newCH group than in controls $\left(\mathrm{FT}_{4} \pm\right.$ s.E.M. $9.2 \pm 0.5$ to $19.7 \pm 1.2$ vs $11.3 \pm 0.5$ to $\left.27.8 .2 \pm 2.4 \mathrm{pmol} / \mathrm{l}, P<0.05\right)$. The $\mathrm{CH}$ group exhibited reduced basal and stimulated $\mathrm{FT}_{4}$ compared with the TSH-sufficient groups. $\mathrm{Tg}$ increased similarly among all study groups after rhTSH injection.

Conclusion: In this pilot study, patients with untreated $\mathrm{CH}$ had lower response to $0.9 \mathrm{mg} \mathrm{rhTSH}$ in $\mathrm{FT}_{4}$ and $\mathrm{rT}_{3}$ than controls. An rhTSH test may be useful in the diagnosis of $\mathrm{CH}$, but further studies are required.
\end{abstract}

European Journal of Endocrinology 159 153-160

\section{Introduction}

Central hypothyroidism $(\mathrm{CH})$ occurs due to insufficient synthesis and secretion of biologically active thyroidstimulating hormone (TSH). It may present as part of a general hypopituitarism or as consequence of a limited pituitary damage. The diagnosis of $\mathrm{CH}$ may often be difficult as serum TSH levels can be both low, normal, or slightly increased (1). The bioactivity of TSH (2) is also reduced because of an inadequate hypothalamic stimulation that causes the pituitary to secrete an abnormally glycosylated TSH. TSH in this form has a longer half-life than normal TSH (3), which explains the normal and sometimes slightly elevated levels of TSH seen in $\mathrm{CH}$. In addition, thyroid hormone levels in mild hypothyroidism may be within the lower normal range (4-7). Because of this uncertainty of using basal thyroid hormone levels in the evaluation of $\mathrm{CH}$, other tests have been developed. Patients with $\mathrm{CH}$ have a blunted nocturnal surge $(8,9)$ in the TSH circadian secretion (10-12). This may, however, be found in non-thyroidal illness (13), in postoperative patients
$(14,15)$, during starvation (16), and in severe primary hypothyroidism (17). The thyrotropin-releasing hormone stimulation test has been used in the diagnosis of $\mathrm{CH}$ $(18,19)$, but its value has been questioned $(20)$. However, authors of a recent study of children with congenital $\mathrm{CH}$ claim the value of the thyrotropin-releasing hormone test to differentiate between isolated $\mathrm{CH}$ and $\mathrm{CH}$ combined with multiple hormonal insufficiencies (21). Hence, the diagnosis of $\mathrm{CH}$ may be difficult and an additional test to clarify the diagnosis is warranted.

In some early studies, bovine TSH (bTSH) stimulation was explored for the diagnosis of $\mathrm{CH}$ (22). In 1949, an increased iodine uptake in the thyroid was detected in normal subjects after bTSH administration that was sustained if the subjects were treated with thyroid hormone during the stimulation (23). It was later established that an inactive gland in $\mathrm{CH}$ can be stimulated to resume thyroid hormone synthesis after numerous bTSH injections (22). However, bTSH usage was terminated due to commonly occurring allergic 
reactions (24) and the appearance of neutralizing and hemagglutinating antibodies $(24,25)$.

Through its receptor, TSH regulates the expression of all gene products required for thyroid hormone synthesis (26-28). TSH receptor knockout mice are, however, able to produce and store thyroglobulin $(\mathrm{Tg})$ that has a low iodine and hormone content (29). In addition, animal studies demonstrate that $\mathrm{Tg}$ synthesis and secretion into the follicular lumen continues in the absence of TSH $(29,30)$. Moreover, subsequent to the elimination of endogenous $\mathrm{TSH}$, the acute endocytic response to TSH is gradually diminished due to the reduction of membrane material available for the formation of endocytotic vesicles (31). Therefore, a different response to TSH in a TSH-depleted thyroid gland than under normal conditions could be expected, which is in analogy with the short adrenocorticotropin (ACTH) stimulation test that is proven to be valid in the diagnosis of ACTH deficiency (32).

The primary aim of the present pilot study was to investigate whether the stimulation of the thyroid gland with recombinant human TSH (rhTSH) could distinguish between patients with $\mathrm{CH}$ and those who are TSH sufficient. The second aim was to investigate the physiology of a TSH-depleted thyroid gland.

\section{Subjects and methods}

\section{Subjects}

Eighteen Caucasian patients with well-defined pituitary disease and pituitary insufficiency were recruited from our endocrine clinic. These patients comprised of three groups: the $\mathrm{CH}$ group $(n=6)$ was treated with levothyroxine (Levaxin, Nycomed AB, Stockholm, Sweden), the newCH group $(n=6)$ had a newly diagnosed $\mathrm{CH}$ not yet replaced, and the nonCH group $(n=6)$ had hypopituitarism but unaffected TSH secretion, which was reflected by normal pre-study free thyroxine $\left(\mathrm{FT}_{4}\right)$ levels (range 11-14 pmol/l). The consecutively recruited newCH patients had an established pituitary disease, a $\mathrm{FT}_{4}$ below the normal range (pre-study mean \pm s.E.M.; range, $\mathrm{FT}_{4}: 7.8 \pm 0.9 \mathrm{pmol} / \mathrm{l}(6.6-8.9) ; \mathrm{TSH}, 0.74 \pm$ $0.62 \mathrm{mU} / \mathrm{l}(0.02-1.9))$, and additional pituitary insufficiencies. Six healthy Caucasian controls were also included. As one control was subnormal in $\mathrm{FT}_{4}$, he was replaced with another individual. The groups were matched for age, sex, and body mass index (Table 1). The exclusion criteria were: current thyroid disease, presence of thyroperoxidase antibodies, cardiac disease and treatment with antiepileptic, antipsychotic, or anticoagulation drugs.

\section{Ethics}

Subjects received oral and written information about the study and were included after giving written informed consent. The study protocol was approved by the Ethics Committee at Göteborg University and the Swedish Medical Products Agency, Uppsala, Sweden. The study was performed according to the Declaration of Helsinki.

\section{Study design}

This was a prospective, randomized single-blinded trial using two doses of rhTSH. Before the start of the study, all subjects underwent a routine clinical investigation, including an electrocardiographic registration. In the

Table 1 Demography of the study population, presented as mean and range, of patients with central hypothyroidism $(\mathrm{CH})$, patients with newly diagnosed $\mathrm{CH}($ newCH), patients with pituitary insufficiency but intact secretion of thyroid-stimulating hormone $(\mathrm{TSH})(\mathrm{nonCH})$ and controls.

\begin{tabular}{|c|c|c|c|c|}
\hline Subjects & NewCH $(n=6)$ & $\mathbf{C H}(n=6)$ & NonCH $(n=6)$ & Controls $(n=6)$ \\
\hline Age (years) mean (range) & $55.7(35-68)$ & $56.2(48-63)$ & $55.7(40-61)$ & $51.8(37-62)$ \\
\hline Sex (female:male) & $2: 4$ & $1: 5$ & $1: 5$ & $1: 5$ \\
\hline BMI $\left(\mathrm{kg} / \mathrm{m}^{2}\right)$ mean (range) & $26.9(23.3-32.0)$ & $26.6(21.7-30.8)$ & $26.0(20.1-30.0)$ & $25.4(21.8-27.8)$ \\
\hline Levothyroxine $(\mu \mathrm{g})$ & 0 & $125(100-150)$ & 0 & 0 \\
\hline \multicolumn{5}{|l|}{ Pituitary insufficiencies (number) } \\
\hline $\mathrm{GH}$ & 6 (unreplaced) & 6 (replaced) & 1 (replaced) & 0 \\
\hline $\mathrm{FSH} / \mathrm{LH}$ & $6^{a}$ & $5^{b}$ & $3^{c}$ & $0^{\mathrm{c}}$ \\
\hline TSH & 6 & 6 & 0 & 0 \\
\hline ACTH & 4 & 4 & 1 & 0 \\
\hline ADH & 0 & 0 & 1 & 0 \\
\hline \multicolumn{5}{|l|}{ Pituitary diagnosis $(n)$} \\
\hline Pituitary adenoma & 5 & 3 & 3 & \\
\hline Histiocytosis & & 1 & 1 & \\
\hline Acromegaly, surgery, cured & & & 1 & \\
\hline Hypopituitarism, idiopathic & & 1 & 1 & \\
\hline $\mathrm{Mb}$ Cushing, surgery & & 1 & & \\
\hline Pituitary apoplexia, surgery & 1 & & & \\
\hline
\end{tabular}

$N=$ number.

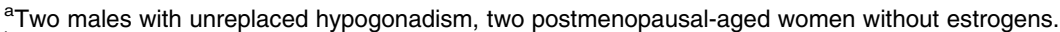

bOne postmenopausal woman on estrogens.

'One postmenopausal woman without estrogens. 
$\mathrm{CH}$ group, the levothyroxine substitution was changed to $20 \mu \mathrm{g}$ tri-iodothyronine $\left(\mathrm{T}_{3}\right.$; Liothyronin, Nycomed $\mathrm{AB}$, Stockholm, Sweden) thrice daily 5 weeks before study start because of its shorter half-life. If symptoms indicating over replacement appeared, the dose was reduced by half. $\mathrm{T}_{3}$ substitution was discontinued 1 week before commencement of the study and levothyroxine substitution was re-instituted after study completion.

All participants received an i.m. gluteal injection at $0900 \mathrm{~h}$ of 0.1 and $0.9 \mathrm{mg}$ rhTSH (Thyrogen, Genzyme, Boston, MA, USA) given in random order with 1 week in-between. Subjects were randomized in blocks by the hospital pharmacy. Before each injection, blood samples were taken for the assessment of hemoglobin, serum sodium, potassium, calcium, creatinine, alanine aminotransferase, aspartate aminotransferase, and alkaline phosphatase. Samples were collected at $-45 \mathrm{~min}$, immediately before and 2, 31/2, 7, 24, 48, and $72 \mathrm{~h}$ after each injection, and a mean was calculated of the two baseline measurements. Side effects were recorded simultaneously. The newCH patients and the replaced control were recruited after the completion of the other study groups. Based on previous experience, less frequent blood sampling was performed in the newCH group: before and 24,48 , and $72 \mathrm{~h}$ after each injection.

After study termination, samples were analyzed for $\mathrm{TSH}, \mathrm{FT}_{4}$, total $\mathrm{T}_{4}\left(\mathrm{TT}_{4}\right)$, free $\mathrm{T}_{3}\left(\mathrm{FT}_{3}\right)$, total $\mathrm{T}_{3}\left(\mathrm{TT}_{3}\right)$, reverse $\mathrm{T}_{3}\left(\mathrm{rT}_{3}\right), \mathrm{Tg}$, and $\mathrm{Tg}$ antibodies. In addition, IGF-I and insulin levels were measured before any rhTSH injection.

\section{Hormonal assays}

Immunochemoluminometric methods (Architect, Abbot) were used for the analyses of TSH (interindividual coefficient of variation $(\mathrm{CV}) 3 \%$, reference range (refr) $0.20-4.0 \mathrm{mIU} / \mathrm{l}), \mathrm{FT}_{4}(\mathrm{CV} 6 \%$ at low level and 5\% at high level, refr 10-22 pmol/l), $\mathrm{TT}_{4}$ (CV 5\%, refr 56-147 nmol/l), $\mathrm{FT}_{3}$ (CV 9\% at low level and 4\% at high level, refr 2.6-5.7 pmol/l), and $\mathrm{TT}_{3}$ (CV 7\% at low level and 3\% at high level, refr $0.9-2.4 \mathrm{nmol} / \mathrm{l}) . \mathrm{RT}_{3}$ was determined by a radioimmunometric assay (Wallac Adaltis, Bologna, Italy, CV 5\%, refr 0.14-0.54 nmol/l). $\mathrm{Tg}$ was analyzed by an immunoflourimetric method (Delphia, Wallac Sweden AB, Turku, Finland, CV 3\% at low level, $8 \%$ at medium level, and $4 \%$ at high level, refr 2-20 $\mu \mathrm{g} / \mathrm{l}$ ). Tg antibodies (Lumitest, Brahms, Henningsdorf, Germany, CV 9\%, refr $<60 \mathrm{U} / \mathrm{ml}$ ) and TPO antibodies (Berilux 400, Perkin-Elmer BRAHMS Diagnostica, Berlin, Germany, CV 11\%, refr <60 kU/l) were measured by immunoluminescense technique. IGF-I was determined with a RIA after acid ethanolic extraction (Nicols Institute Diagnostics, San Juan Capistrano CA, USA, CV 6.3\% at low level, 6.5\% at medium level, and $7.7 \%$ at high level) and insulin by a chemoluminometric method (Advia Centaur, Bayer Corporation, Tarrytown, NY, USA, CV 5\% at low level and 6\% at medium and high level). Specimens were analyzed in the same batch, except for the newCH specimens and the exchanged control specimens that were analyzed separately but with the same immunoassays, except, in the control, for IGF-I that was determined by Immulite 2500, DPC, Siemens, Los Angeles, CA, USA.

\section{Statistical methods}

Descriptive data are presented as mean \pm s.E.M. The effect before and after rhTSH administration was analyzed with paired $t$-test and comparisons of hormone levels between groups were performed with unpaired $t$-test. Statistical significance was considered if $P<0.05$.

\section{Results}

All subjects completed the study, however, one control was unable to leave specimens twice. One patient on $\mathrm{T}_{3}$ substitution experienced headache and nausea, and one tiredness; their dose was reduced by half according to the study protocol. Symptoms after the rhTSH administrations were mild and transient. Marked symptoms of hypothyroidism $(n=1)$ and a brief period of chest pain not related to ischemic heart disease $(n=1)$, occurred in the $\mathrm{CH}$ group. Tiredness was, otherwise, the most frequent symptom (newCH $n=1, \mathrm{CH} n=5$, and nonCH $n=1$ ) followed by sensation of warmth (newCH $n=1$ and controls $n=2$ ), nocturnal perspiration (controls $n=2$ ), slight discomfort (controls $n=2$ ), palpitation (controls $n=1$ ), pain in the calves (controls $n=1$ ), dizziness (nonCH $n=1)$, and less nocturia (nonCH $n=1)$.

In subjects randomized to receive $0.9 \mathrm{mg}$ as first dose, the hormonal levels had not completely returned to baseline before the next injection. Baseline was, therefore, characterized as the values before any rhTSH administration and compared with peak levels after each injection. Moreover, the response in thyroid hormones from $0.1 \mathrm{mg}$ rhTSH was less pronounced compared with the $0.9 \mathrm{mg}$ dose response and did not discriminate new $\mathrm{CH}$ patients from controls. The emphasis in the results section is therefore on the $0.9 \mathrm{mg}$ rhTSH dose.

\section{TSH}

Basal levels of TSH did not differ between groups. After rhTSH injection, serum TSH increased similarly in the four groups to a peak of $16.1 \pm 6.0 \mathrm{mIU} / \mathrm{l}$ after $0.1 \mathrm{mg}$ and $>100 \mathrm{mIU} / \mathrm{l}$ after $0.9 \mathrm{mg}$ within the first $24 \mathrm{~h}$, results of groups combined (Table 2 ).

\section{Thyroglobulin}

Basal Tg levels were similar in all groups. In $\mathrm{CH}$ subjects, basal Tg levels were increased before the second injection, regardless of given dose (data not shown). RhTSH stimulation resulted in a distinct and comparable increase in $\mathrm{Tg}$ in all groups, with similar peak 
Table 2 Basal and peak serum levels of thyroid-related hormones and thyroglobulin after $0.9 \mathrm{mg}$ rhSH in patients with treated central hypothyroidism $(\mathrm{CH})$, patients with newly diagnosed $\mathrm{CH}(\mathrm{newCH})$, patients with pituitary insufficiency but intact secretion of thyroidstimulating hormone (TSH) (nonCH) and controls.

\begin{tabular}{|c|c|c|c|c|}
\hline Analytes & NewCH $(n=6)$ & $\mathrm{CH}(n=6)$ & NonCH $(n=6)$ & Controls $(n=6)$ \\
\hline \multicolumn{5}{|l|}{ TSH (mU/l) } \\
\hline Basal & $0.95 \pm 0.25$ & $1.15 \pm 0.57$ & $1.49 \pm 0.19$ & $1.47 \pm 0.29$ \\
\hline \multicolumn{5}{|c|}{ Thyroglobulin $(\mu \mathrm{g} / \mathrm{l})$} \\
\hline Basal & $3.7 \pm 0.5$ & $5.7 \pm 1.1$ & $7.9 \pm 2.0$ & $3.4 \pm 0.5$ \\
\hline Peak & $68.3 \pm 15.2$ & $164 \pm 89.6$ & $79.3 \pm 12.3$ & $53.2 \pm 8.9$ \\
\hline \multicolumn{5}{|l|}{$\mathrm{FT}_{4}(\mathrm{pmol} / \mathrm{l})$} \\
\hline Basal & $9.2 \pm 0.5^{*}$ & $<5.2 \pm 0.0^{\ddagger}$ & $11.6 \pm 0.9$ & $11.3 \pm 0.5$ \\
\hline Peak & $19.7 \pm 1.2^{*}$ & $6.4 \pm 0.6^{\ddagger}$ & $30.0 \pm 4.3$ & $27.8 \pm 2.4$ \\
\hline \multicolumn{5}{|l|}{$\mathrm{TT}_{4}(\mathrm{nmol} / \mathrm{l})$} \\
\hline Basal & $57.0 \pm 5.2^{*}$ & $19.6 \pm 2.9^{\ddagger}$ & $77.8 \pm 7.0$ & $72.6 \pm 3.3$ \\
\hline Peak & $140.0 \pm 9.3$ & $38.7 \pm 7.3^{\ddagger}$ & $178 . \overline{3} \pm 20.6$ & $161.7 \pm 14.3$ \\
\hline \multicolumn{5}{|l|}{$\mathrm{FT}_{3}(\mathrm{pmol} / \mathrm{l})$} \\
\hline Basal & $3.2 \pm 0.4$ & $1.9 \pm 0.2^{\ddagger}$ & $4.2 \pm 0.3$ & $4.2 \pm 0.1$ \\
\hline Peak & $8.4 \pm 0.8$ & $3.7 \pm 0.7^{\ddagger}$ & $10 . \overline{0} \pm 0.7$ & $10 . \overline{4} \pm 1.0$ \\
\hline \multicolumn{5}{|l|}{$\mathrm{TT}_{3}(\mathrm{nmol} / \mathrm{l})$} \\
\hline Basal & $1.2 \pm 0.1$ & $0.6 \pm 0.1^{\ddagger}$ & $1.4 \pm 0.1$ & $1.5 \pm 0.0$ \\
\hline Peak & $3.0 \pm 0.2$ & $1.4 \pm 0.3^{\ddagger}$ & $3.4 \pm 0.2$ & $3.4 \pm 0.2$ \\
\hline \multicolumn{5}{|l|}{$\mathrm{RT}_{3}(\mathrm{nmol} / \mathrm{l})$} \\
\hline Basal & $0.26 \pm 0.06$ & $0.01 \pm 0.01^{\ddagger}$ & $0.37 \pm 0.05$ & $0.33 \pm 0.01$ \\
\hline Peak & $0.43 \pm 0.04^{\dagger}$ & $0.10 \pm 0.04^{\ddagger}$ & $0.77 \pm 0.14$ & $0.66 \pm 0.04$ \\
\hline \multicolumn{5}{|c|}{ Insulin (mU/l) } \\
\hline Basal & $23.5 \pm 6.1$ & $15.1 \pm 3.0$ & $41.2 \pm 31.9$ & $14.2 \pm 4.7$ \\
\hline \multicolumn{5}{|l|}{ IGF-I ( $\mu \mathrm{g} / \mathrm{l})$} \\
\hline Basal & $98 \pm 18^{\dagger}$ & $242 \pm 21$ & $189 \pm 38$ & $186 \pm 12$ \\
\hline
\end{tabular}

In addition, fasting serum insulin and IGF-I levels are presented. Data are presented as mean \pm S.E.M. $n=$ number of patients. ${ }^{\star} P<0.05,{ }^{\dagger} P<0.01,{ }^{\ddagger} P<0.001$ newCH, $\mathrm{CH}$ and nonCH groups versus controls.

levels $48 \mathrm{~h}$ after the $0.9 \mathrm{mg}$ dose (Fig. $1 \mathrm{~A}$ and Table 2). In the $\mathrm{CH}$ group, an extreme outlier $(\max \mathrm{Tg} 600 \mu \mathrm{g} / \mathrm{l})$ occurred and after the exclusion of this subject, the Tg analyses did not differ between groups (Fig. 1A).

\section{$\mathrm{FT}_{4}$ and $\mathrm{TT}_{4}$}

The nonCH and control groups had similar baseline $\mathrm{FT}_{4}$ levels (range 8.6-14.5 and 10-13.0 pmol/l respectively), whereas $\mathrm{FT}_{4}$ levels in the $\mathrm{CH}$ group were low (Table 2). The lowest $\mathrm{FT}_{4}$ in the nonCH group was a mean of $\mathrm{FT}_{4} 9.8$ and $7.3 \mathrm{pmol} / \mathrm{l} \mathrm{FT}_{4}$ in the newCH group (range: $7.8-11.0 \mathrm{pmol} / \mathrm{l}$ ) was lower than in control subjects but higher than in $\mathrm{CH}$ patients. After the administration of $0.9 \mathrm{mg}$ rhTSH, the increase in the newCH group was less pronounced than in controls (Figs 1B, 2A and 3A). A small overlap in the peak $\mathrm{FT}_{4}$ level occurred between the two groups, range: newCH $15-23 \mathrm{pmol} / \mathrm{l}$ and controls 20-36 pmol/l. Overlapping values were seen in 67 and $50 \%$ of newCH patients and controls after 0.9 and $0.1 \mathrm{mg}$ rhTSH respectively. However, the lowest $\mathrm{FT}_{4}$ level in the controls after $0.9 \mathrm{mg}$ rhTSH was from one subject unable to leave specimens on two out of three occasions where $\mathrm{FT}_{4}$ used to peak. If this patient was excluded from the overlap analysis, no overlap existed between the newCH and the control group after $0.9 \mathrm{mg}$ rhTSH. The mean increase of $\mathrm{FT}_{4}$ after the high-dose stimulation was in the newCH group $10.5 \mathrm{pmol} / \mathrm{l}$ (range 7-13.2) and in controls $16.5 \mathrm{pmol} / \mathrm{l}$ (range 10.0-23.5, $P<0.05$ ). The $\mathrm{FT}_{4}$ concentration peaked after 48 or $72 \mathrm{~h}(n=10$, $n=2$ respectively). A much smaller increase in $\mathrm{FT}_{4}$ was observed in the $\mathrm{CH}$ group and no overlap was detected with the TSH-sufficient subjects (Figs 2A and $3 \mathrm{~A}$ ). In the $\mathrm{CH}$ group, however, basal levels of $\mathrm{FT}_{4}$ were higher before the second than before the first injection of rhTSH, regardless of the dose administrated (data not shown). Serum $\mathrm{TT}_{4}$ concentrations displayed a similar pattern as $\mathrm{FT}_{4}$.

\section{$\mathrm{FT}_{3}$ and $\mathrm{TT}_{3}$}

Baseline serum levels of $\mathrm{FT}_{3}$ and $\mathrm{TT}_{3}$ were similar in the nonCH patients and controls, whereas reduced levels were observed in the $\mathrm{CH}$ group (Table 2). In the newCH group, $\mathrm{FT}_{3}$ levels were lower than in controls, but higher than in the $\mathrm{CH}$ group. After $0.9 \mathrm{mg}$ rhTSH, a marked increase in $\mathrm{FT}_{3}$ and $\mathrm{TT}_{3}$ was seen in newCH patients, nonCH patients, and controls (Figs $2 \mathrm{~B}$ and $3 \mathrm{~B}$ ). However, there was a considerable overlap comparing the rhTSH response of the newCH group and the TSHsufficient patients.

\section{$\mathrm{RT}_{3}$}

NewCH groups, nonCH groups, and controls did not differ in baseline $\mathrm{rT}_{3}$ (Table 2). The $\mathrm{CH}$ group had decreased levels compared with the other groups. After 


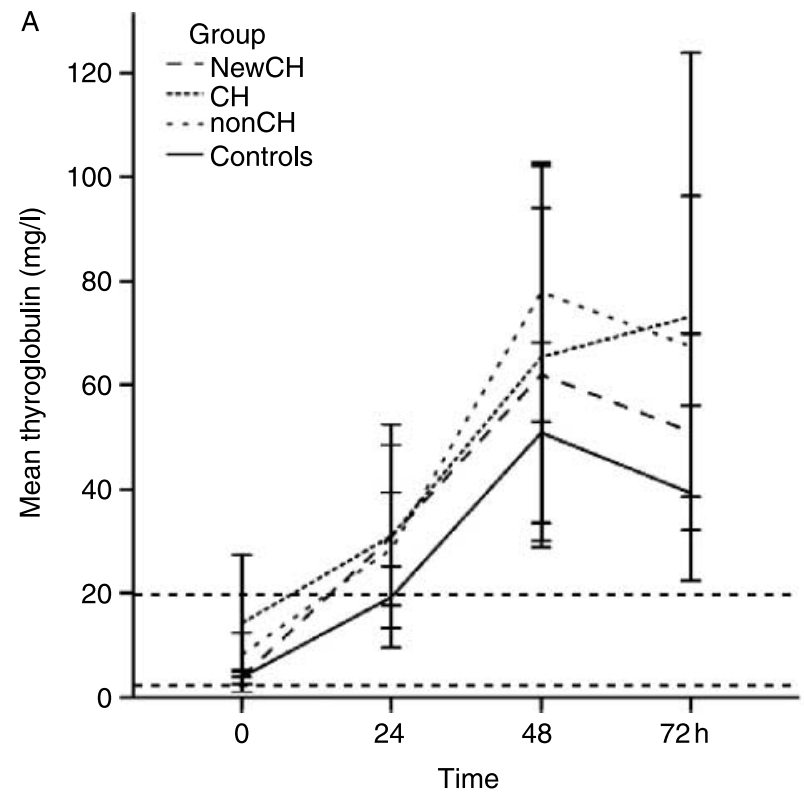

Error bars: \pm 2 S.E.M.

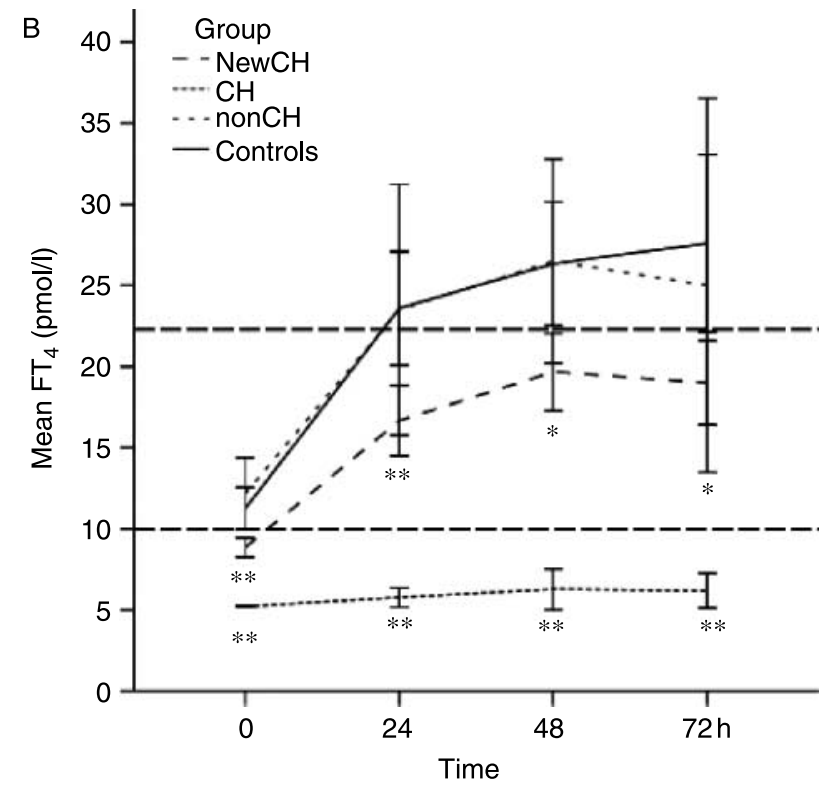

Error bars: \pm 2 S.E.M.

Figure $1 \mathrm{RhTSH}$ response of $0.9 \mathrm{mg}$ dose in six patients with previous treated central hypothyroidism $(\mathrm{CH})$, six newly diagnosed $\mathrm{CH}$ (newCH), six patients with hypopituitarism without $\mathrm{CH}($ nonCH) compared to six healthy controls in thyroglobulin $(A)$ (without an extreme outlier in the $\mathrm{CH}$ group), and FT4 (B). ${ }^{\star} P<0.05,{ }^{\star \star} P<0.01$ newCH- or $\mathrm{CH}$-group vs controls. Values are mean. Error bars $=$ S.E.M. The horizontal broken lines represent normal range.

the high-dose rhTSH stimulation, a less pronounced increase was observed in the newCH patients than in controls. The $\mathrm{CH}$ group had a lower response than newCH (Figs 2C and 3C). Stimulated $\mathrm{rT}_{3}$ levels did not differ between TSH-sufficient groups. A small overlap was detected in the increase and the maximum $\mathrm{rT}_{3}$ levels after high-dose stimulation: mean $\delta \mathrm{rT}_{3}$ in newCH patients $0.17 \mathrm{nmol} / \mathrm{l}$ (range -0.02 to 0.40 ) and in controls $0.34 \mathrm{nmol} / \mathrm{l}$ (range $0.26-0.46$ ),$P<0.05$ and peak range in newCH group $0.32-0.56 \mathrm{nmol} / \mathrm{l}$ and in controls $0.56-0.81 \mathrm{nmol} / \mathrm{l}$. The peak occurred after 48 or $72 \mathrm{~h}$ in the majority of cases.

\section{IGF-I and insulin}

The serum IGF-I level from the replaced control was not included in analysis as methods differed (Table 2). Serum IGF-I levels were decreased in the newCH group compared with controls and the GH replaced patients in the $\mathrm{CH}$ group. Fasting serum insulin levels did not differ among the groups.

\section{Discussion}

This pilot study has explored the response of the thyroid gland to rhTSH in adults with and without TSH deficiency. Patients with newly diagnosed $\mathrm{CH}$ and no previous levothyroxine treatment exhibited a less pronounced increase of thyroid hormone levels after administration of $0.9 \mathrm{mg}$ rhTSH than controls. An rhTSH test may, therefore, become useful in the diagnosis of $\mathrm{CH}$. Notably, patients with and without TSH deficiency displayed a similar increase in serum Tg levels in response to rhTSH.

In multiple pituitary hormone deficiency, the determination of peripheral thyroid hormones is usually enough in the diagnosis of $\mathrm{CH}$. Nevertheless, some of the newCH subjects exhibited baseline $\mathrm{FT}_{4}$ values within the normal range. This is probably best explained by 'regression to the mean' as their low thyroid hormone level was used for selection into the study. This is also illustrated by the nonCH patient with a baseline $\mathrm{FT}_{4}$ of 8.6 , which was a mean of two analyses: $\mathrm{FT}_{4} 9.8$ and $7.3 \mathrm{pmol} / \mathrm{l}$. In addition, the six controls had mean $\mathrm{FT}_{4}$ concentrations in the lower part of the normal range by chance. The newCH group had significantly lower baseline $\mathrm{FT}_{4}$ levels than controls, although there was some overlap.

By including well-characterized hypopituitary patients with sufficient TSH production, we explored the possibility of subjects having partial $\mathrm{CH}$. The results in baseline and stimulated thyroid hormone levels in the nonCH group were, however, consistent with controls; hence, no evidence of partial $\mathrm{CH}$ existed. Nonetheless, in clinical work, newly diagnosed $\mathrm{CH}$ patients may exhibit $\mathrm{FT}_{4}$ levels in the low normal or subnormal range (7). This is explained by the small intra-individual variation, commonly $\pm 25 \%$, of thyroid hormone levels (4). Subsequently, a $\mathrm{CH}$ patient may have considerably reduced circulating thyroid hormone levels, but still exhibit $\mathrm{FT}_{4}$ levels within the lower normal reference interval $(5,6)$.

The aims of this study were to investigate whether the rhTSH test was sufficient as a diagnostic device and to 

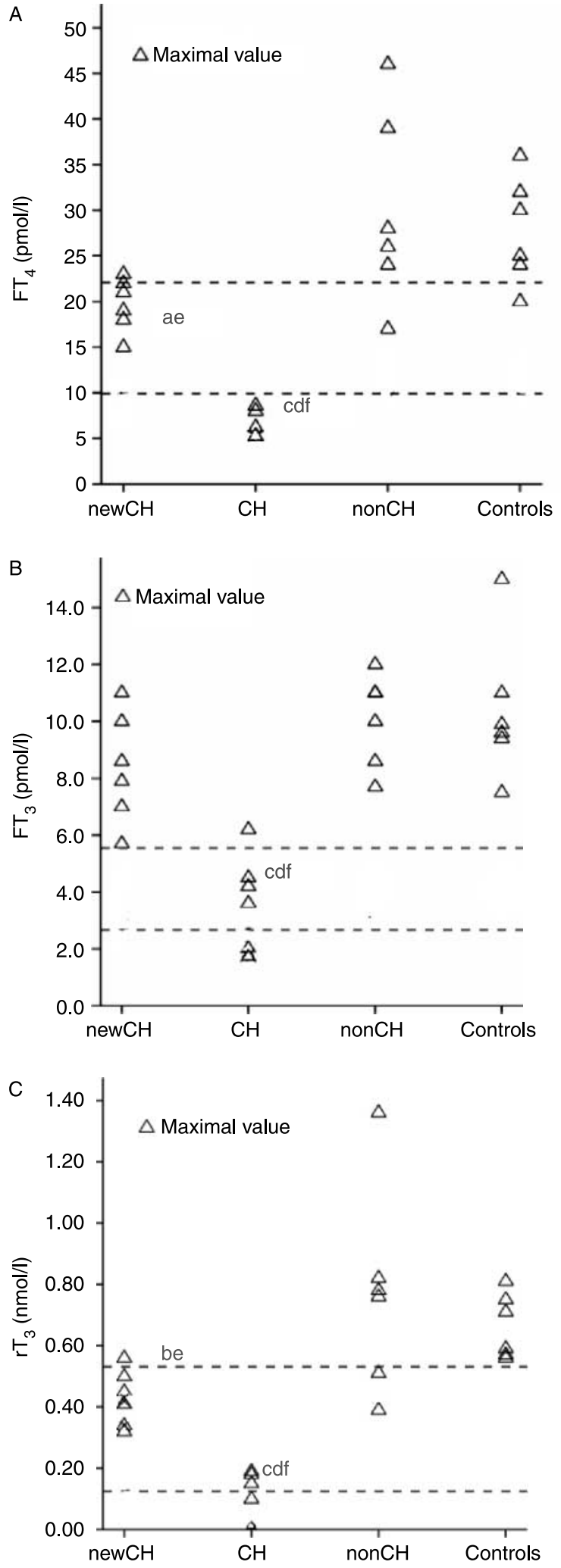

evaluate the response of the thyroid gland to rhTSH in $\mathrm{CH}$ patients. The decreased thyroid hormone response to rhTSH was most pronounced in the $\mathrm{CH}$ group. These results are, however, difficult to interpret because of previous levothyroxine replacement. Therefore, it is more appropriate to investigate newly diagnosed untreated $\mathrm{CH}$ patients. Although the response to $0.9 \mathrm{mg}$ rhTSH in $\mathrm{FT}_{4}$ and $\mathrm{rT}_{3}$ was reduced in newCH patients, the test did not entirely discriminate patients with $\mathrm{CH}$ from controls. However, this shall be interpreted with caution as two peak data were missing on one control. The discriminative value may therefore be better than that observed in this study. In addition, under the circumstances of unreplaced growth hormone deficiency (GHD) $\mathrm{FT}_{4}$ may be higher than under $\mathrm{GH}$ treatment because of a decreased peripheral deiodination of $\mathrm{T}_{4}$ to $\mathrm{T}_{3}$. NewCH patients with untreated GHD may therefore have higher $\mathrm{FT}_{4}$ levels than they would have if $\mathrm{GH}$ treated. Therefore, the $\mathrm{CH}$ of the newCH patients may be more severe than what is illustrated from $\mathrm{FT}_{4}$ levels. Nonetheless, the rhTSH test may identify patients with $\mathrm{CH}$ if $\mathrm{rT}_{3}<0.56 \mathrm{nmol} / \mathrm{l}$ or $\mathrm{FT}_{4}<20 \mathrm{pmol} / \mathrm{l} 48-72 \mathrm{~h}$ after $0.9 \mathrm{mg}$ of rhTSH (exact figures assay specific). Moreover, no newCH patient had an increment of $\mathrm{FT}_{4}>14 \mathrm{pmol} / \mathrm{l}$. Consequently, in patients with suspected $\mathrm{CH}$, the rhTSH test may be used as an adjuvant diagnostic tool.

The low-dose rhTSH $(0.1 \mathrm{mg})$ was not as sensitive as the $0.9 \mathrm{mg}$ dose to detect $\mathrm{CH}$, still, the experience from the ACTH stimulation test indicates that a low dose may be more useful in ACTH deficiency than in primary adrenal failure $(33,34)$. However, rhTSH stimulations in patients with nodular goiter demonstrated that a dose of $0.3 \mathrm{mg}$ is as potent as $0.9 \mathrm{mg}$ to increase the iodine uptake (35). Therefore, $0.3 \mathrm{mg}$ rhTSH may be an option in $\mathrm{CH}$ to minimize the risk of cardiac side effects, even though the $0.9 \mathrm{mg}$ dose was well tolerated in this study.

Before the availability of rhTSH, an increase $\mathrm{I}^{131}$ thyroid uptake was observed after multiple repeated bTSH injections in patients with $\mathrm{CH}$ (22), demonstrating that a dormant gland could be activated. However, these studies were performed before the introduction of sensitive immunomethods to determine thyroid hormones and, therefore, no radioiodine uptake was performed in this study. However, patients with severe $\mathrm{CH}$ (CH group) produced higher thyroid hormones level after the second rhTSH injection, regardless of dose. This is most likely due to the activation of the thyroidal cellular system by TSH increasing the iodine content of the thyroid gland and thereby making it more responsive to the next stimuli (22).

Figure 2 Peak levels after $0.9 \mathrm{mg}$ rhTSH in six patients with central hypothyroidism $(\mathrm{CH})$, six patients with newly diagnosed $\mathrm{CH}$ (newCH), six patients with hypopituitarism but regarded TSHsufficient (nonCH) and six healthy controls for FT4 (A), FT3 (B) and rT3 (C). The broken line represents the normal range. $a=P<0.05$, $\mathrm{b}=P<0.01, \mathrm{c}=P<0.001$ non- $\mathrm{CH}$-, newCH- or $\mathrm{CH}$-group vs controls. $\mathrm{d}=P<0.01 \mathrm{CH}$ - vs nonCH-group, $\mathrm{e}=P<0.05$ newCH- vs nonCH-group. $\mathrm{f}=\mathrm{P}<0.05 \mathrm{CH}$ - vs newCH-group. 

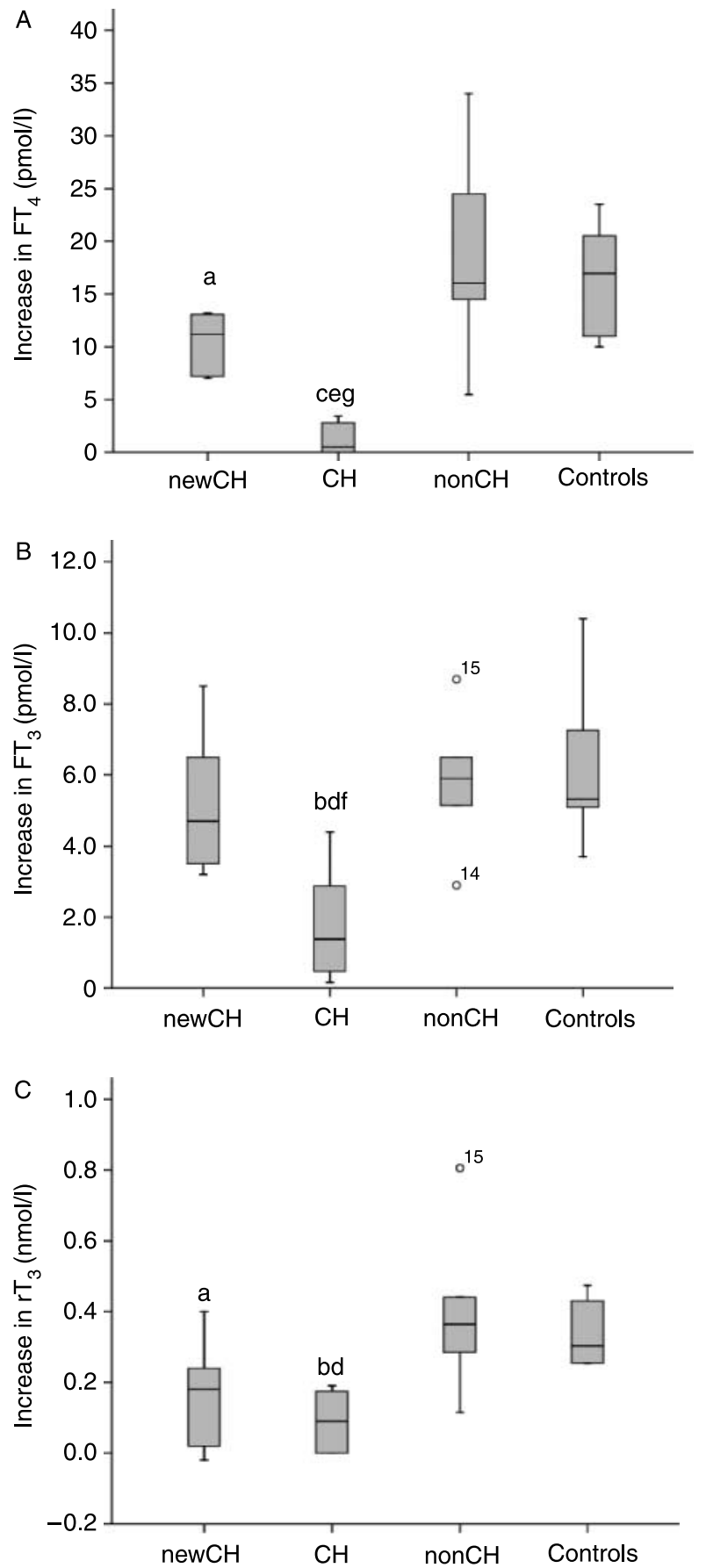

Figure 3 The increase of FT4 (A), FT3 (B) and rT3 (C) after $0.9 \mathrm{mg}$ rhTSH in six patients with central hypothyroidism $(\mathrm{CH})$, six patients with newly diagnosed $\mathrm{CH}$ (newCH), six patients with hypopituitarism but considered TSH-sufficient (nonCH) and six healthy controls. $\mathrm{a}=P<0.05, \mathrm{~b}=P<0.01, \mathrm{C}=P<0.001$ non- $\mathrm{CH}-$, newCH- or $\mathrm{CH}$-group vs controls. $\mathrm{d}=P<0.05, \mathrm{e}=P<0.01 \mathrm{CH}$ - vs nonCH-group. $\mathrm{f}=P<0.01, \mathrm{~g}=P<0.001 \mathrm{CH}$ - vs newCH-group.

The rhTSH-induced $\mathrm{Tg}$ response in $\mathrm{CH}$ patients indicates that the diminished response in thyroid hormones was not due to unresponsiveness of the TSH receptor of thyroid follicular cells. As endocytosis and, consequently, the removal of $\mathrm{Tg}$ from the lumen are diminished, the net result is a gradual accumulation of poorly iodinated $\mathrm{Tg}(29)$. This low-iodinated $\mathrm{Tg}$ has a low hormone content; hence, a smaller amount of hormones are released from the thyroid after TSH stimulation. This is probably the main reason for the blunted thyroid hormone response to rhTSH found in the two patient groups with $\mathrm{CH}$. Individuals within the $\mathrm{CH}$ group probably had a less iodinated $\mathrm{Tg}$ compared with newCH individuals, most of whom apparently had a partial stimulation of the thyroid with low, but detectable levels of thyroid hormones. Therefore, the sensitivity of this suggested diagnostic tool may be lower in mild cases of $\mathrm{CH}$.

The normal $\mathrm{Tg}$ levels in $\mathrm{CH}$ contradicts, however, a reduction in the endocytosis of $\mathrm{Tg}$. As the amount of $\mathrm{Tg}$ increases in the absence of TSH, the high concentration in the lumen may allow a large amount of $\mathrm{Tg}$ to be taken into the cell by endocytosis, in spite of the reduction in the volume of the endocytotic compartment. Moreover, although the major regulator of $\mathrm{Tg}$ synthesis is TSH $(27,28)$, insulin and IGF-I are able to stimulate Tg synthesis in the absence of TSH $(30,36)$. Insulin levels did not differ between groups and normal serum IGF-I levels were found in all groups except for the newCH group, where IGF-I levels were low, reflecting untreated GH deficiency. A reduction of basal Tg levels could, therefore, be suspected in the newCH group. Hence, in addition to accumulation of $\mathrm{Tg}$ in the lumen, some other factor, yet unknown, may contribute to the normal Tg production in TSH insufficiency.

In conclusion, patients with $\mathrm{CH}$ have an attenuated increase in serum $\mathrm{FT}_{4}$ and $\mathrm{rT}_{3}$ in response to $0.9 \mathrm{mg}$ rhTSH compared with healthy controls. This observation may be useful in the diagnostic procedure of patients with suspected $\mathrm{CH}$. However, further studies are needed to establish optimal dose and cut-off levels before implementation of the rhTSH test can occur in clinical practice.

\section{Acknowledgements}

We thank Prof. Lars Ericsson, Department of Anatomy, Anna-Lena Jönsson, and colleagues at the Department of Endocrinology, Sahlgrenska University Hospital for their contributions. This study was supported by grants from the Sahlgrenska academy at Göteborg University, the Göteborg Medical Society and the Swedish Medical Society. RhTSH was provided by Genzyme, Boston, MA, USA.

\section{References}

1 Patel YC \& Burger HG. Serum thyrotropin (TSH) in pituitary andor hypothalamic hypothyroidism: normal or elevated basal levels and paradoxical responses to thyrotropin-releasing hormone. Journal of Clinical Endocrinology and Metabolism 197337 190-196. 
2 Persani L, Ferretti E, Borgato S, Faglia G \& Beck-Peccoz P. Circulating thyrotropin bioactivity in sporadic central hypothyroidism. Journal of Clinical Endocrinology and Metabolism 2000 85 3631-3635.

3 Persani L. Hypothalamic thyrotropin-releasing hormone and thyrotropin biological activity. Thyroid $1998 \mathbf{8} 941-946$.

4 Andersen S, Pedersen KM, Bruun NH \& Laurberg P. Narrow individual variations in serum $\mathrm{T}(4)$ and $\mathrm{T}(3)$ in normal subjects: a clue to the understanding of subclinical thyroid disease. Journal of Clinical Endocrinology and Metabolism 200287 1068-1072.

5 Yamakita N, Komaki T, Takao T, Murai T, Hashimoto K \& Yasuda K. Usefulness of thyrotropin (TSH)-releasing hormone test and nocturnal surge of TSH for diagnosis of isolated deficit of TSH secretion. Journal of Clinical Endocrinology and Metabolism 200186 1054-1060.

6 Rose SR, Lustig RH, Pitukcheewanont P, Broome DC, Burghen GA, Li H, Hudson MM, Kun LE \& Heideman RL. Diagnosis of hidden central hypothyroidism in survivors of childhood cancer. Journal of Clinical Endocrinology and Metabolism $1999844472-4479$.

7 Agha A, Walker D, Perry L, Drake WM, Chew SL, Jenkins PJ, Grossman AB \& Monson JP. Unmasking of central hypothyroidism following growth hormone replacement in adult hypopituitary patients. Clinical Endocrinology 200766 72-77.

8 Caron PJ, Nieman LK, Rose SR \& Nisula BC. Deficient nocturnal surge of thyrotropin in central hypothyroidism. Journal of Clinical Endocrinology and Metabolism $1986 \mathbf{6 2} 960-964$.

9 Rose SR, Manasco PK, Pearce S \& Nisula BC. Hypothyroidism and deficiency of the nocturnal thyrotropin surge in children with hypothalamic-pituitary disorders. Journal of Clinical Endocrinology and Metabolism 199070 1750-1755.

10 Patel YC, Alford FP \& Burger HG. The 24-hour plasma thyrotrophin profile. Clinical Science $19724371-77$.

11 Vanhaelst L, Van Cauter E, Degaute JP \& Golstein J. Circadian variations of serum thyrotropin levels in man. Journal of Clinical Endocrinology and Metabolism 197235 479-482.

12 Weeke J. Circadian variation of the serum thyrotropin level in normal subjects. Scandinavian Journal of Clinical and Laboratory Investigation $197331337-342$.

13 Romijn JA \& Wiersinga WM. Decreased nocturnal surge of thyrotropin in nonthyroidal illness. Journal of Clinical Endocrinology and Metabolism 199070 35-42.

14 Monig H, Stracke L, Arendt T \& Kloehn S. Blunted nocturnal TSH surge does not indicate central hypothyroidism in patients after pituitary surgery. Experimental and Clinical Endocrinology and Diabetes $1999 \mathbf{1 0 7} 89-92$.

15 Bartalena L, Martino E, Brandi LS, Falcone M, Pacchiarotti A, Ricci C, Bogazzi F, Grasso L, Mammoli C \& Pinchera A. Lack of nocturnal serum thyrotropin surge after surgery. Journal of Clinical Endocrinology and Metabolism 1990 70 293-296.

16 Romijn JA, Adriaanse R, Brabant G, Prank K, Endert E \& Wiersinga WM. Pulsatile secretion of thyrotropin during fasting: a decrease of thyrotropin pulse amplitude. Journal of Clinical Endocrinology and Metabolism 1990 70 1631-1636.

17 Weeke J \& Laurberg P. Diural TSH variations in hypothyroidism. Journal of Clinical Endocrinology and Metabolism 197643 32-37.

18 Faglia G, Beck-Peccoz P, Ferrari C, Ambrosi B, Spada A, Travaglini P \& Paracchi S. Plasma thyrotropin response to thyrotropin-releasing hormone in patients with pituitary and hypothalamic disorders. Journal of Clinical Endocrinology and Metabolism 197337 595-601.

19 Faglia G. The clinical impact of the thyrotropin-releasing hormone test. Thyroid $1998 \mathbf{8} 903-908$.
20 Hartoft-Nielsen ML, Lange M, Rasmussen AK, Scherer S, Zimmermann-Belsing $\mathrm{T} \&$ Feldt-Rasmussen U. Thyrotropinreleasing hormone stimulation test in patients with pituitary pathology. Hormone Research 200461 53-57.

21 van Tijn DA, de Vijlder JJ \& Vulsma T. Role of the thyrotropinreleasing hormone stimulation test in diagnosis of congenital central hypothyroidism in infants. Journal of Clinical Endocrinology and Metabolism 200893 410-419.

22 Querido A \& Stanbury JB. Primary and secondary hypothyroidism. Journal of Clinical Endocrinology and Metabolism $1950 \quad 10$ 1192-1201.

23 Stanley MM \& Astwoor EB. The response of the thyroid gland in normal human subjects to the administartion of thyrotropin as shown by studies with I131. Endocrinology 1949 44 49-60.

24 Robbins J. Pharmacology of bovine and human thyrotropin: an historical perspective. Thyroid $19999451-453$.

25 Hays MT, Solomon DH \& Werner SC. The effect of purified bovine thyroid-stimulating hormone in men. II. Loss of effectiveness with prolonged administration. Journal of Clinical Endocrinology and Metabolism 196121 1475-1482.

26 Dunn JT \& Dunn AD. Update on intrathyroidal iodine metabolism. Thyroid 200111 407-414.

27 Van Heuverswyn B, Streydio C, Brocas H, Refetoff S, Dumont J \& Vassart G. Thyrotropin controls transcription of the thyroglobulin gene. PNAS 198481 5941-5945.

28 Ossendorp FA, Leer LM, Bruning PF, van den Brink JA, Sterk A \& de Vijlder JJ. Iodination of newly synthesized thyroglobulin by FRTL- 5 cells is selective and thyrotropin dependent. Molecular and Cellular Endocrinology 198966 199-205.

29 Marians RC, Ng L, Blair HC, Unger P, Graves PN \& Davies TF. Defining thyrotropin-dependent and -independent steps of thyroid hormone synthesis by using thyrotropin receptor-null mice. PNAS $20029915776-15781$.

30 Santisteban P, Kohn LD \& Di Lauro R. Thyroglobulin gene expression is regulated by insulin and insulin-like growth factor I, as well as thyrotropin, in FRTL-5 thyroid cells. Journal of Biological Chemistry 1987262 4048-4052.

31 Ericson LE, Engstrom G \& Ekholm R. Effects of long term thyroxine treatment on thyrotropin-induced exocytosis and endocytosis in the rat thyroid. Endocrinology $1979 \mathbf{1 0 4} 704-710$.

32 Lindholm J, Kehlet H, Blichert-Toft M, Dinesen B \& Riishede J. Reliability of the 30-minute ACTH test in assessing hypothalamicpituitary-adrenal function. Journal of Clinical Endocrinology and Metabolism 197847 272-274.

33 Rasmuson S, Olsson T \& Hagg E. A low dose ACTH test to assess the function of the hypothalamic-pituitary-adrenal axis. Clinical Endocrinology $1996 \mathbf{4 4} 151-156$.

34 Filipsson H \& Johannsson G. Management of glucocorticoid replacement in adult growth hormone deficiency. Hormone Research 200767 (Suppl 1) 155-164.

35 Duick DS \& Baskin HJ. Utility of recombinant human thyrotropin for augmentation of radioiodine uptake and treatment of nontoxic and toxic multinodular goiters. Endocrine Practice 20039 204-209.

36 Clement S, Refetoff S, Robaye B, Dumont JE \& Schurmans S. Low TSH requirement and goiter in transgenic mice overexpressing IGF-I and IGF-Ir receptor in the thyroid gland. Endocrinology 2001 142 5131-5139.

Received 29 April 2008

Accepted 16 May 2008 